\title{
THE SCIENTIFIC BASIS FOR THE CREATION OF NEW FORMS OF MICROBIAL BIOCHEMICALS
}

\section{A.P. KOZHEMYAKOV ${ }^{1}$, Yu.V. LAKTIONOV ${ }^{1}$, T.A. POPOVA ${ }^{1}$, A.G. ORLOVA ${ }^{1}$, A.L. KOKORINA ${ }^{2}$, O.B. VAISHLYA ${ }^{3}$, E.V. AGAFONOV ${ }^{4}$, S.A. GUZHVIN ${ }^{4}$, A.A. CHURAKOV 5 , M.T. YAKOVLEVA ${ }^{6}$}

${ }^{1}$ All-Russian Research Institute for Agricultural Microbiology, Federal Agency of Scientific Organizations, 3, sh. Podbel'skogo, St. Petersburg, 196608 Russia, e-mail kojemyakov@rambler.ru, laktionov@list.ru, yanevich-2@mail.ru; ${ }^{2}$ Saint Petersburg State Agrarian University, 2/1, Sankt-Peterburgskoe sh., St. Petersburg, 196608 Russia, e-mail spbgau@mail.ru;

3Tomsk State University, 36, pr. Lenina, Tomsk, 634050 Russia, e-mail plantaplus@list.ru;

${ }^{4}$ Donskoi State Agrarian University, pos. Persianovskii, Oktyabr'skii Region, Rostov Province, 346493 Russia, e-mail sguujvin@rambler.ru;

5 Krasnoyarsk State Agrarian University, 66, pr. Svobodnyi, Krasnoyarsk, 660041 Russia, e-mail a-tjn@ay.ru;

${ }^{6}$ Yakutsk Research Institute of Agriculture, Federal Agency of Scientific Organizations, 23/1, ul. BestuzhevaMarlinskogo, Yakutsk, 677001 Russia, e-mail maryatimofeevna@mail.ru

Acknowledgements:

Supported by EurAsEC program «Innovative biotechnologies», State Contract № 14. M04.12.0011.

Received March 30, 2015

\section{Abstract}

Herein we summarize the results of a comprehensive study aimed on the creation of liquid form of biological products for symbiotic and associative rhizobacteria. The objects of study were nodule bacteria from the rhizosphere of galegae (Rhizobium galegae), soybean (Bradyrhizobium japonicum) and associative rhizobacteria (Arthrobacter mysorens, Azospirillum brasilense, Agrobacterium radiobacter), as well as plants of soybean (Glycine max L.), barley (Hordeum L.), alfalfa (Medicago L.), etc. As carriers for bacteria, we used gamma-sterile peat, vermiculite and improved sterile liquid media on the basis of components of vegetable or synthetic origin, with the introduction of nutrients and stabilizers (humates, glycerine, potassium sorbate, carboxymethylcellulose, etc.). The efficacy of tested products and forms were compared in a biological survey carried out in different regions of the Russian Federation. Under the conditions of Leningrad Region the effectiveness was evaluated for the preparations based on recently used and perspective strains of alfalfa nodule bacteria Sinorhizobium meliloti. An optimized combination of stabilizers, nutrients and protective substrates provided a long-term storage and high efficiency of biological products. Nevertheless, plant nutrient media (bean broth) did not provide the required quality. Using bean medium for cultivation it is possible to obtain the desired titer of bacteria in the product, but their numbers are rapidly decreasing. Furthermore, preparations obtained with use of bean broth lose quality after 2-3 months after the beginning of storage because of extraneous microflora therein. The new forms of biochemicals designed on the basis of a synthetic nutrient medium can be stored at room temperature for at least 6 months, when sterile-packed in plastic bottles. High bacteria titer (3.6-4.2 billion $\mathrm{CFU} / \mathrm{ml}$ of liquid formulation) was obtained after cultivation. It is shown that an improved liquid form has a high efficiency. Its application on leguminous plants increased grain yield by $20-40 \%$ in soy, and by $15-25 \%$ in peas. Productivity of cereal crops (wheat, barley) increased by $15-25 \%$, and the productivity of alfalfa was $20-45 \%$ higher. A significant increase in crop quality was found to be due to higher protein content. The effectiveness of biological products considerably depended on agroecological conditions and biological features of the crops. Using different strains of nodule bacteria Sinorhizobium meliloti in the Leningrad Region allowed us to create the effective plantmicrobe systems. Thus on the sod-podzolic soil the strain A-4 was most effective providing yield increase by more than $25 \%$, while on sod-carbonate soil it was the strain A-5 which increased the productivity of alfalfa by $140 \%$. cal products.

Keywords: biological product, nodule bacteria, rhizobacteria association, forms of biologi-

Microbial biochemicals provide a cost-effective and environmentally friendly way to increase plant productivity [1-5]. Providing plants with nitrogen is 
a particularly significant advantage of microbial and plant symbioses.

The process of manufacturing and use of mineral nitrogen fertilizers is extremely energy consuming: it consumes up to $50 \%$ of the total energy of the agro-industrial complex. It is not possible to solve the problem of energy conservation without cheaper and environmentally friendly biological nitrogen [6-9].

Seed inoculation has been known for over 100 years. Preparations based on nodule bacteria have been produced in different forms, such as soil inoculated with nodule bacteria, products based on peat (sterile and non-sterile) and on solid carriers (perlite, vermiculite, wood, or coconut chips), paste, gel and liquid formulations [10-15].

The main problems hindering the widespread use of the majority of soil fertilizing biologics are the lack of easy-to-use, reliable and efficient, and inexpensive forms based on rhizosphere microorganisms producing spores. Culturing and long-term preservation of the latter alive is associated with certain technological difficulties. Liquid form of inoculants is the most promising technological and economical form, being a nutrient medium with rhizobacteria grown in it. It allows simplifying the production process by eliminating the stages of substrate preparation and inoculation [16, 17].

Culture media based on natural products are complex and vary with the quality and origin of the starting material. This technology was developed several decades ago, and its greatest disadvantage is a short shelf life of the product liquid form. With liquid culture, bacteria titer starts to decrease sharply in 10-15 days [18].

The aim of this work was to create an efficient and technologically advanced soil fertilizing biochemicals for a wide range of crops (cereals, legumes, fodder plants, vegetables) and comparative assessment of the efficacy of traditional and new forms of biological products in different agro-ecological conditions.

Technique. Our study was focused on nodule bacteria from the rhizosphere of galegae (Rhizobium galegae), soybean (Bradyrhizobium japonicum) and associative rhizobacteria (Arthrobacter mysorens, Azospirillum brasilense, Agrobacterium radiobacter). Also soybean (Glycine max L.), barley (Hordeum L.), alfalfa (Medicago L.) plants, etc., were used. Gamma-sterile peat, sterile vermiculite and liquid media based on the components of vegetable or synthetic origin, with the introduction of nutrients and stabilizers (humates, glycerine, potassium sorbate, carboxymethylcellulose - CMC, etc.) served as carriers for the bacteria.

Studies were performed on the basis of Geography Network Experiments with soil fertilizing biochemicals under various agro-ecological conditions.

Field experiments were laid in Leningrad (Saint Petersburg State Agricultural University - SAU; alfalfa Medicago varia L. variety Agnes), Rostov (Donskoi SAU, soybean Glycine max L. variety Vilan), Bryansk (Bryansk State University - SU; barley Hordeum L. variety Zaozersky 85), Orel (All-Russian Institute of Legumes; soybean Glycine max L. variety Lantsetnaya) and Tomsk (Tomsk State University; alfalfa Medicago sativa L., alfalfa M. lupulina L., and eastern vetch Galega orientalis L.) regions, and in Krasnoyarsk Territory (Krasnoyarsk SAU; soybean Glycine max L. variety SIBNIIK 315).

Production and perspective strains of nodule bacteria isolated from soil and nodules of plants growing in various regions of the world, and associative nitrogen-fixing bacteria isolated from different soil and plant rhizosphere, were used in the experiments [19].

Under the conditions of Leningrad Region, the effectiveness was evaluated for the preparations based on recently used and perspective strains of alfalfa nodule bacteria. Experiments were held at the experimental field of Saint Peters- 
burg SAU in sod-podzolic (pH 5.9; humus content of $2.4 \%$ ) and sod-carbonate (pH 6.5; humus content of $2.8 \%$ ) cultivated soils.

Production $(415 \mathrm{~b}, 425 \mathrm{a})$ and advanced (A-3, A-4, A-5, A-6) strains of nodule bacteria Sinorhizobium meliloti from the collection of the All-Russian Research Institute of Agricultural Microbiology (RCAM, St. Petersburg) were used as inoculants.

Prior to sowing, seeds were wounded and inoculated with microbial preparations under the experiment scheme. Line sowing with row spacing of $30 \mathrm{~cm}$ was used. Fertilizers have not been used within the study. Alfalfa was cultivated according to the technology conventional for Leningrad Region.

The obtained data were processed using analysis of variance and multivariate analysis [20].

Results. The optimum ratios of various nutrients and protective components have been selected in previous studies, allowing the shelf life of products to reach 2 months at low temperature.

Plant nutrient media (bean broth) did not provide the required product quality (Table 1). The use of bean medium for cultivation made it possible to obtain the desired titer of bacteria in the product, but their numbers were rapidly decreasing. The initial titer of soybean nodule bacteria liquid preparations was 3.1-4.5 billion $\mathrm{CFU} / \mathrm{ml}$, and after 2 months the number of bacteria was reduced twice down to $1.7-2.1$ billion $\mathrm{CFU} / \mathrm{ml}$. After 3 months, the product titers dropped dramatically down to 3.1-6.1 million $\mathrm{CFU} / \mathrm{mL}$ and continued to decrease at a high rate. Furthermore, preparations obtained with the use of bean broth lose quality in 2-3 months after the beginning of storage due to the extraneous microflora therein.

1. Titers $\left(\times 10^{6} \mathrm{CFU} / \mathrm{ml}\right)$ of liquid preparations based on vetch nodule bacteria (Rhizobium galegae, strain 912) with various components added into the legume medium and at different storage temperatures (laboratory experiment)

\begin{tabular}{|c|c|c|c|c|c|c|}
\hline \multirow{3}{*}{ Version } & \multicolumn{6}{|c|}{ Shelf life, temperature } \\
\hline & \multicolumn{2}{|c|}{2 weeks } & \multicolumn{2}{|c|}{4 weeks } & \multicolumn{2}{|c|}{8 weeks } \\
\hline & $18-21^{\circ} \mathrm{C}$ & $4-6^{\circ} \mathrm{C}$ & $18-21^{\circ} \mathrm{C}$ & $4-6^{\circ} \mathrm{C}$ & $18-21{ }^{\circ} \mathrm{C}$ & $4-6^{\circ} \mathrm{C}$ \\
\hline Control & 610 & 3,400 & 61 & 740 & 34 & 8 \\
\hline Humate, $1 \%$ & 830 & 7,100 & 360 & 62 & 41 & 47 \\
\hline Glycerol, $1 \%$ & 2,300 & 1,200 & 410 & 820 & 57 & 450 \\
\hline Glycerol, $2 \%$ & 1,200 & 760 & 80 & 300 & 20 & 300 \\
\hline Glycerol, $1 \%+$ humate, $1 \%$ & 430 & 210 & 31 & 140 & 4.3 & 100 \\
\hline Potassium sorbate, $1 \%$ & 4,100 & 3,200 & 150 & 1,800 & 110 & 1,200 \\
\hline Potassium sorbate, $2 \%$ & 730 & 2,700 & 28 & 650 & 14 & 300 \\
\hline Carboxymethylcellulose, $1 \%$ & 810 & 2,800 & 210 & 280 & 67 & 780 \\
\hline $\begin{array}{l}\text { Potassium sorbate, } 1 \%+\text { carboxy- } \\
\text { methylcellulose, } 1 \%\end{array}$ & 1,200 & 1,400 & 340 & 440 & 60 & 840 \\
\hline $\mathrm{LSD}_{05}$ & 36.7 & 94.2 & 31.0 & 47.0 & 6.1 & 36.4 \\
\hline
\end{tabular}

In recent years, an absolutely new synthetic type of media for the culture of beneficial microorganisms has been developed [21, 22]. Synthetic media are prepared of chemically pure organic and inorganic compounds, taken in exactly specified concentrations. Constant composition is an important advantage of synthetic media, so they are easily reproducible.

Our data proved that it is advisable to use these media for the products based on nodule bacteria (Table 2). In contrast to the natural media (bean broth), contamination is generally not observed in synthetic media during storage. Furthermore, it is possible to more accurately adjust the content of nutrients in the medium and their ratio, which is not possible in case of a broth as its composition varies depending on the preparation time, quality, raw material grade, and many other factors. 
2. Titers $\left(\times 10^{6} \mathrm{CFU} / \mathrm{ml}\right)$ of various soybean Bradyrhizobium japonicum nodule bacteria strains in liquid product with synthetic medium (storage temperature of $22-25^{\circ} \mathrm{C}$ ) (laboratory experiment)

\begin{tabular}{c|c|c|c|c|c|c|c}
\hline \multirow{2}{*}{ Strain } & \multicolumn{7}{c}{ Shelf life } \\
\cline { 2 - 8 } & 1 day & 14 days & 1 month & 2 months & 3 months & 5 months & 6 months \\
\hline $634 \mathrm{~b}$ & $3.8 \pm 0.40$ & $3.7 \pm 0.25$ & $3.7 \pm 0.26$ & $3.5 \pm 0.30$ & $3.1 \pm 0.20$ & $2.8 \pm 0.20$ & $2.7 \pm 0.15$ \\
$640 \mathrm{~b}$ & $3.6 \pm 0.40$ & $3.6 \pm 0.31$ & $3.5 \pm 0.30$ & $3.5 \pm 0.26$ & $3.2 \pm 0.26$ & $2.9 \pm 0.26$ & $2.8 \pm 0.23$ \\
$645 \mathrm{~b}$ & $4.2 \pm 0.32$ & $4.1 \pm 0.42$ & $3.9 \pm 0.24$ & $3.8 \pm 0.37$ & $3.0 \pm 0.34$ & $2.8 \pm 0.23$ & $2.7 \pm 0.35$ \\
\hline
\end{tabular}

With the new synthetic nutrient medium, high bacteria titers (3.6-4.2 billion $\mathrm{CFU} / \mathrm{ml}$ of liquid formulation) could be obtained after cultivation. New medium made it possible to maintain high bacteria titers for 6 months without product quality reduction. The results obtained in the framework of the Geography Network Experiments showed that the efficacy of the products prepared with synthetic media after 6 months of storage were not inferior to fresh products based on traditional liquid medium and peat [23].

Presowing treatment of large amounts of seeds is currently associated with certain difficulties. According to the recommendations, it should be performed on the day of seeding without access to sunlight. This problem can be solved by developing methods of mechanized application of microbiological preparations to soil at sowing. In this case, no additional processing is required prior to sowing; processing is carried out directly by the sowing machine in the field. This approach will contribute to the wider introduction of inoculants in agriculture, and hence to high crop yields.

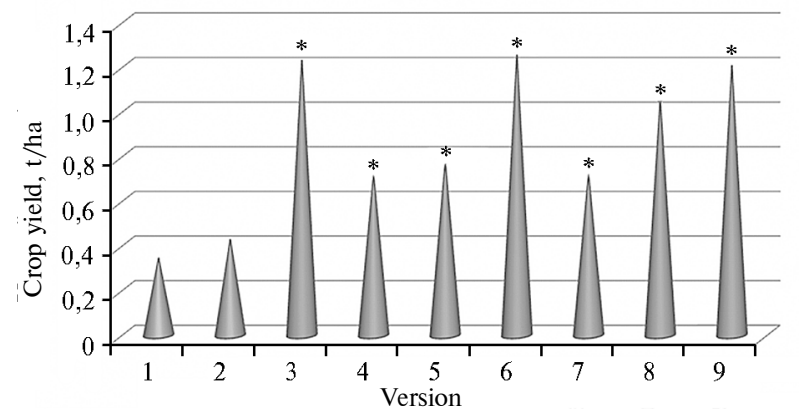

Fig. 1. Soybean SIBNIIK 315 yield with seed treatment with various forms of biochemicals based on Bradyrhizobium japonicum: 1 - control, 2 - strain 634b (with peat), 3 - strain 634b (liquid medium), 4 - strain $634 \mathrm{~b}$ (with vermiculite), 5 - strain 626a (with peat), 6 - strain 626a (liquid media), 7 - strain 626a (with vermiculite), 8 - strain $640 \mathrm{~b}$ (with peat), 9 - strain 645b (with peat) (Krasnoyarsk district, 2014).

* Significant differences to control.
Comparative effectiveness of biological products based on sterile peat, vermiculite, and liquid medium was studied in different regions of the Russian Federation in cereals (winter and spring wheat, barley, rice), legumes (soybean, pea) and fodder crops (alfalfa, vetch) (data partially shown).

In experiments with soybeans in the Krasnoyarsk district (Fig. 1), the liquid form of biological product increased productivity almost 4-fold, and the peat form and the vermiculite-based product increased grain yield 2-fold on average. In general, that high effectiveness is due to the lack of «native» strains of nodule bacteria specific to soybeans. In similar cases, the use of inoculants is agronomically necessary [24].

Under the conditions of Rostov Region, all three forms (peat, vermiculite, and liquid) of the biological product based on nodule bacteria Bradyrhizobium japonicum (strain 626a) were shown to contribute to a significant increase in soybean yields. In control version, it was $20.3 \mathrm{c} / \mathrm{ha}$, under seed treatment with the biochemical based of peat it was $23.1 \mathrm{c} / \mathrm{ha}$, and in cases of the vermiculite and the liquid form it reached $25.0 \mathrm{c} /$ ha and $24.4 \mathrm{c} /$ ha, respectively (Fig. 2).

At gray forest soil of Bryansk Region, solid forms (based on peat and vermiculite) increased barley yield by 5-10\%; in case of the liquid form, it was 
$12-16 \%$ higher.

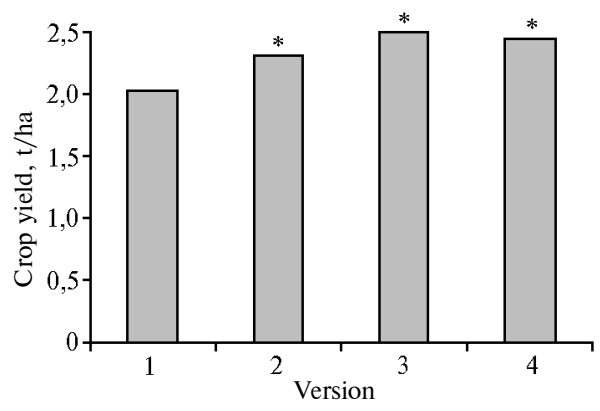

Fig. 2. Soybean Vilana yield with seed treatment with various forms of biochemicals based on nodule bacteria Bradyrhizobium japonicum: (strain 626a): 1 - control, 2 - with peat, $3-$ with vermiculite, 4 - liquid medium (Rostov Region, 2012-2014).

* Significant differences to control.
Under the conditions of Orel Region, soybean grain yield increased by $6 \%$ with the use of the product based on peat and by $12 \%$ with the liquid form of the biochemical (compared to the control without seed inoculation). At black soil of Rostov Region, soybean grain yield increased by $19 \%$ in case of the peat form and by $25 \%$ with the liquid form; in peas, these figures were 17 and $23 \%$, respectively. High efficiency of alfalfa inoculation was obtained at gray forest soils of Tomsk Region, where the increase was $20-70 \%$ in case of peat products and $30-90 \%$ with the liquid form.

Selection and screening of promising strains of microorganisms based on agro-ecological conditions are important conditions for the increasing of biochemical efficacy.

3. Dry weight alfalfa Agnes yield (t/ha) with seed inoculation with vatious strains of nodule bacteria Sinorhizobium meliloti depending on soil type (Leningrad Region)

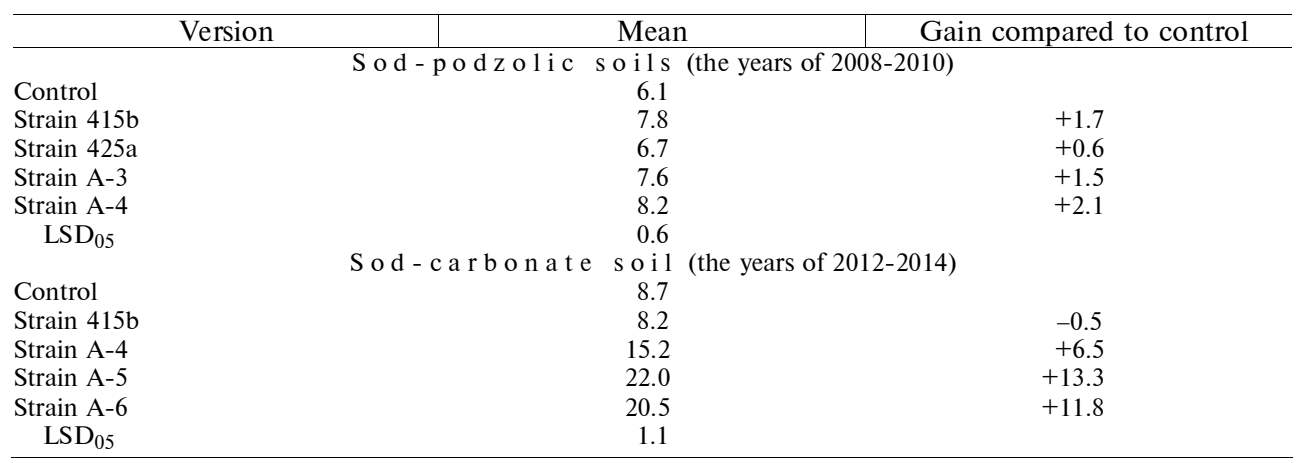

Thus, using different strains of nodule bacteria Sinorhizobium meliloti in Leningrad Region for seed inoculation prior to alfalfa sowing allowed us to create the effective plant-microbe systems. On the sod-podzolic soil, strain A-4 was most effective providing yield increase by more than $25 \%$ and grain yield of $2.1 \mathrm{t} / \mathrm{ha}$ of dry weight, while on sod-carbonate soil it was the strain A-5 which increased the productivity of alfalfa by $140 \%$; the dry weight gain compared to control was 13.3 and $11.8 \mathrm{t} / \mathrm{ha}$, respectively when strains A-5 and A-6 were used for inoculation (Table 3 ).

Thus, a method of field evaluation of the efficacy of new forms of microbial biochemicals that improve productivity and quality of crops has been developed. The new type of synthetic nutrient media has been shown to be suitable for liquid bacterial preparations. Productivity of plants with the use of new formulations is not inferior (or even superior) to traditional forms. Studied biochemicals are convenient for use and hi-tech products. The favorable effect of inoculation on soil fertility and ecological environment should be taken into account as well.

\section{REFERENCES}

1. Z Z vali in A.A. Biopreparaty, udobreniya i urozhai [Biologicals, fertilizers and crop yield]. Moscow, 2005. 
2. Tikhonovich I.A., Kruglov Yu.V., Kozhemyakov A.P., Chebotar' V.K., Kandybin N.V., Laptev G.Yu. Biopreparaty $V$ sel'skom khozyaistve [Biologicals in agriculture]. Moscow, 2005.

3. B lagoveshchenski i G.V., Voitovich I.V., Shtyrkhunov V.D., Ol'khov y i V.E. Kormoproizvodstvo, 2003, 4: 20-23.

4. Eme l'y nova A.G., Y a k ov leva M.T., K o z he m y a k o v A.P. Priem uluchsheniya plodorodiya merzlotnykh pochv s ispol'zovaniem inokulyatsii semyan lyutserny zheltoi shtammami kluben'kovykh $i$ assotsiativnykh bakterii. Metodicheskoe posobie [Improving permafrost soil fertility by inoculation of yellow alfalfa seeds with nodule and associative bacteria]. Yakutsk, 2014.

5. K o z h m y a k v A.P., T i m o f e v a S.V., P o p o v a T.A. Zashchita $i$ karantin rastenii, 2008, 2: 42-43.

6. M is hust i n E.N. V sbornike: Mineral'nyi $i$ biologicheskii azot $v$ zemledelii SSSR [In: Mineral and biological nitrogen in agriculture of the USSR]. Moscow 1985: 3-11.

7. K o z h e m y a k o v A.P. Mikrobiologicheskii zhurnal, 1997, 59(4): 22-28.

8. B everidge C.A., M athesius U., R os e R.J., Gress hoff P. Common regulatory themes in meristem development and whole-plant homeostasis. Curr. Opin. Plant Biol., 2007, 10: 44-51 (doi: 10.1016/j.pbi.2006.11.011).

9. Marra L.M., Fonseca Sousa Soares C.R., Oliveira S.M., Avelar Ferreir a P.A., S o a res B.L. Biological nitrogen fixation and phosphate solubilization by bacteria isolated from tropical soils. Plant Soil, 2012, 357: 289-307 (doi: 10.1007/s11104-012-1157-z).

10. K h o t y a n o v i h A.V. Metody kul'tivirovaniya azotfiksiruyushchikh bakterii, sposoby poIucheniya i primenenie preparatov na ikh osnove (metodicheskie rekomendatsii) [Nitrogenfixing bacteria cultivation, biologicals' production and application: recommendations]. Leningrad, 1991.

11. Tittabutr P., Payakapong W., Teaum roong N., Singleton P.W., Boonk e rd N. Growth, survival and field performance of bradyrhizobial liquid inoculant formulations with polymeric additives. Science Asia, 2007, 33: 69-77.

12. Albareda M., Rodriguez-Navarro D.N., C a macho M., Te mprano F.J. Alternatives to peat as a carrier for rhizobia inoculants: solid and liquid formulations. Soil Biol. Biochem., 2008, 40: 2771-2779 (doi: 10.1016/j.soilbio.2008.07.021).

13. Covarrubias S.A., d e-Bashan L.E., Moreno M., Bashan Y. Alginate beads provide a beneficial physical barrier against native microorganisms in wastewater treated with immobilized bacteria and microalgae. Appl. Microbiol. Biotechnol., 2012, 93(6): 2669-2680 (doi: 10.1007/s00253-011-3585-8).

14. Denton M.D., Pearce D.J., Ballard R.A., Hannah M.C., Mutch L.A., Norng S. A multi-site field evaluation of granular inoculants for legume nodulation. Soil Biol. Biochem., 2009, 41: 2508-2516 (doi: 10.1016/j.soilbio.2009.09.009).

15. Di a z-Zorit a M., Fernand e z-C a n i g i a M.V. Field performance of a liquid formulation of Azospirillum brasilense on dry land wheat productivity. Eur. J. Soil Biol., 2009, 45: 311 (doi: 10.1016/j.ejsobi.2008.07.001).

16. J o h n R.P., Ty a g i R.D., B ra r S.K., Prevost D. Development of emulsion from rhizobial fermented starch industry wastewater for application as Medicago sativa seed coat. Eng. Life Sci., 2010, 10: 248-256.

17. La kt i o n o v Yu.V. Bakterial'nye preparaty [Bacterial biologicals]. LAP LAMBERT Academic Publishing, 2011 (ISBN 978-3-8433-1137-3).

18. Laktionov Yu.V., Popova T.A., Andreev O.A., Ibatullina R.P., Koz h e m y a k o v A.P. Sel'skokhozyaistvennaya biologiya [Agricultural Biology], 2011, 3: 116-118 (http://www.agrobiology.ru/3-2011laktionov-eng.html).

19. Ti k ho novi c h I. A., K o z h e m y a k o v A.P., P r o v o r o v N.A. Genetic potential of plants for improving the beneficial microbe interactions. NATO ASI series. In: Biological fixation of nitrogen for ecology and sustainable agriculture. Berlin, 1997: 191-194.

20. B e li mov A.A., Vo rob'e v N.I., K o z he m y k ov A.P. Byulleten' VNIISKhM, 1989, 52: 6-12.

21. La k ti o nov Yu.V., K o z h e m y a k ov A.P. Materialy dokladov 7-i konferentsii «Perspektivy ispol'zovaniya novykh form udobrenii, sredstv zashchity i regulyatorov rosta rastenii $v$ agrotekhnologiyakh sel'skokhozyaistvennykh kul'tur» [Proc. $7^{\text {th }}$ Conf. «Prospects for the use of new forms of fertilizers, plant protection products and plant growth regulators in agrotechnology».]. Anapa, 2012: 86-87.

22. Laktionov Yu.V., Popova T.A., And reev O.A., I bat u 11 ina R.P., Koz h e m y a k o v A.P. V sbornike: Sovremennye podkhody v biotekhnologii Respubliki Tatarstan [In: Recent approach to biotechnology in the Republic of Tatarstan]. Kazan', 2013: 34-38.

23. Laktionov Yu.V., B e lobrova S.N., Kozhemyakov A.P., Vorob'ev N.I., S e rga li e v N.Kh., A m e nova R.K. Plodorodie, 2013, 5: 24-25.

24. B e rest e t s k i i O.A., D o ro s i n s k i i L.M., K o z h e m y a k o v A.P. Izvestiya AN SSSR, seriya biologicheskaya, 1987, 5: 670-679. 